\title{
Food safety knowledge, attitudes and practices of institutional food-handlers in Ghana
}

\author{
Fortune Akabanda*, Eli Hope Hlortsi and James Owusu-Kwarteng
}

\begin{abstract}
Background: In large scale cooking, food is handled by many individuals, thereby increasing the chances of food contamination due to improper handling. Deliberate or accidental contamination of food during large scale production might endanger the health of consumers, and have very expensive repercussions on a country. The purpose of this study was to evaluate the food safety knowledge, attitudes, and practices among institutional food- handlers in Ghana.

Methods: The study was conducted using a descriptive, cross-sectional survey of 29 institutions by conducting face to face interview and administration of questionnaire to two hundred and thirty-five (235) institutional food-handlers. The questionnaire was peer-reviewed and pilot tested in three institutions in the Upper East Region of Ghana, before the final version was distributed to food-handlers. The questionnaire was structured into five distinctive parts to collect information on (i) demographic characteristics, (ii) employees' work satisfaction, (iii) knowledge on food safety, (iv) attitudes towards food safety and (v) food hygiene practices.

Results: Majority of the food-handlers were between 41-50 years (39.1\%). Female respondents were (76.6\%). In our study, the food-handlers were knowledgeable about hygienic practices, cleaning and sanitation procedures. Almost all of the food-handlers were aware of the critical role of general sanitary practices in the work place, such as hand washing (98.7\% correct answers), using gloves (77.9\%), proper cleaning of the instruments/utensils (86.4\%) and detergent use (72.8\%). On disease transmission, the results indicates that $76.2 \%$ of the food- handlers did not know that Salmonella is a food borne pathogens and $70.6 \%$ did not know that hepatitis A is a food borne pathogen. However, $81.7 \%$ handlers agreed that typhoid fever is transmitted by food and $87.7 \%$ agreed that bloody diarrhea is transmitted by food. Logistic regression analysis testing four models showed statistically significant differences $(p<0.05)$, for models in which the explanatory variable was the level of education.
\end{abstract}

Conclusions: In generally, the institutional food-handlers have satisfactory knowledge in food safety but this does not translate into strict hygienic practices during processing and handling food products.

Keywords: Food-handlers, Food safety, Ghana, Hygienic practices

\section{Background}

When food is cooked on a large scale, it may be handled by many individuals and thus increasing the chances of contamination of the final food. Unintended contamination of food during large scale cooking, leading to food-borne disease outbreaks can pose danger to the health of consumers and economic consequence for nations [1-3].

\footnotetext{
* Correspondence: fakabanda@gmail.com

Department of Applied Biology, Faculty of Applied Sciences, University for Development Studies, P. O. Box 24, Navrongo Campus, Ghana
}

Food-borne related illnesses have increased over the years, and negatively affected the health and economic well-being of many developing nations [4]. The World Health Organization (WHO) states that about 1.8 million persons died from diarrheal diseases in 2005, mainly due to the ingestion of contaminated food and drinking water. Food poisoning occurs as a result of consuming food contaminated with microorganisms or their toxins, the contamination arising from inadequate preservation methods, unhygienic handling practices, cross-contamination from food contact surfaces, or from persons harboring the 
microorganisms in their nares and on the skin $[5,6]$. Unhygienic practices during food preparation, handling and storage creates the conditions that allows the proliferation and transmission of disease causing organisms such as bacteria, viruses and other food-borne pathogens $[7,8]$. Additionally, many reported cases of food-borne viral diseases have been attributed to infected food-handlers involved in catering services [9].

In Ghana, both public and private institutions often have food service or catering units where meals are served to both staff and clients. Such institutions may include schools, research institutes, hospitals and prisons. To prevent outbreak of food-borne diseases in these institutions, high standards of hygienic and safety practices by foodhandlers are essential parts of an overall food safety program implemented by these institutions. Although institutional food-handlers may possess the required knowledge and skills needed in food safety practice, errors due to human handling are often cited in several food-borne disease outbreaks [10-12]. As Greig et al. [11] reports, about 97\% of reported food poisoning cases are due to the improper handling of foods by persons involved in catering services.

The knowledge, attitudes and practices of food-handlers have been reported in studies from different countries around world [13-18]. This is because a combination the three factors: knowledge, attitude and practice of foodhandlers, play dominant role in food safety with regards to food service industry [19]. In Ghana, previous studies have evaluated the knowledge, attitudes and practices of foodhandlers in selected hotels in Accra [2], and food hygiene practices by street food vendors [20]. Recently, food safety knowledge, attitudes and self-reported practices of food handlers in institutional foodservice in Accra-Ghana has also been reported [21]. All these studies were however limiting in scope as they were restricted to only Accra, the capital city. At the moment, there is no published report on the knowledge, attitude and practice of food-handlers in institution selected from different geographical regions of Ghana. Such studies are however, important as they provide a nation-wide assessment of training needs, attitudinal changes and effectiveness of training and education to provide continuous consumer assurance of the safety of food. Such investigations will also provide better understanding of the interactions of prevailing food safety knowledge, attitudes and practices of food-handlers throughout the country, Ghana.

This study therefore sought to assess the knowledge, attitudes, and practices of institutional food-handlers in Ghana, with regard to food hygienic practices and over-all safety.

\section{Methods}

\section{Study population}

A total of 235 institutional food-handlers participated in the study. A descriptive, cross-sectional survey of 29 institutions was employed in this study. The institutions included ten (10) Senior High Schools, nine (9) District Hospitals, two (2) Prison Services, six (6) Universities/ Polytechnics and one (1) Health Research Center located in 5 administrative regions including Upper East, Northern, Ashanti, Volta, Brong-Ahafo and Eastern regions of Ghana (Fig 1).

\section{Interviews}

Face-to-face interviews were conducted using structured questionnaire to collect information on the knowledge, attitudes and practices of the food-handlers on food safety. The questionnaire was peer-reviewed and pilot tested in three institutions in the Upper East Region of Ghana, before a final version was administered to foodhandlers. Participants were interviewed by the researchers and trained research assistants using the structured questionnaire. Data was collected between December 2014 and June 2015.

The questionnaire was structured into five distinctive sections. Section one was to collect information on respondents' demographic characteristics such as gender, age, level of education and length of employment in the food service business. Section two was concerned with information on the employees' work satisfaction while

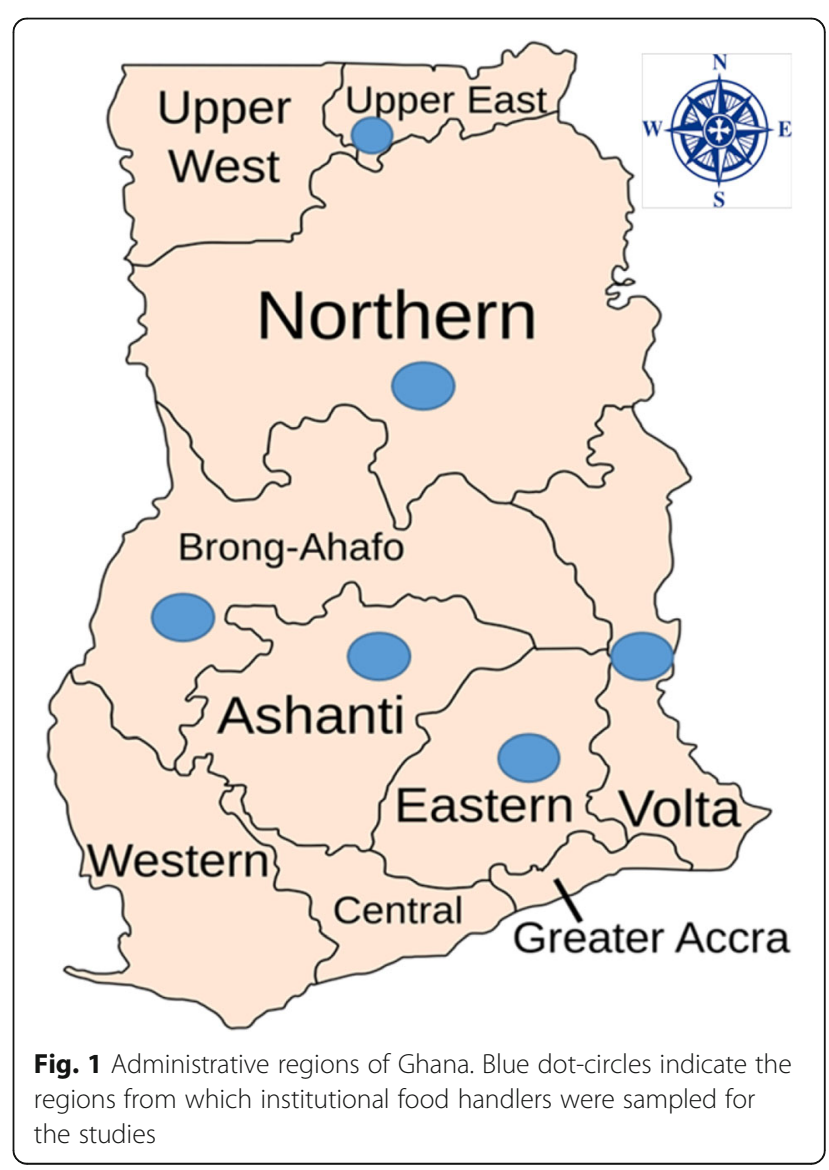


sections 3,4 and 5 were concerned with information on employees' knowledge of food safety, attitude towards food safety and food hygiene practices respectively.

Questions pertaining to demographic information of respondents and employees' work satisfaction were adapted from Soares et al. [22] and Jevšnik et al. [16]. Answers were graded on a scale of five, with 1 indicating "strongly disagree" and five indicating "strongly agree". Questions on food safety knowledge, attitudes and practices were adapted from previously published works [13, 22-24].

The section of questionnaire dealing with food safety knowledge comprised 25 close-ended questions with three possible answers; "true", "false", and "do not know". These questions specifically dealt with respondents' knowledge of personal hygiene, cross contamination, food-borne diseases, microorganisms, temperature control and hygienic practices. A scale ranging between 0 and 24 (representing the total number of questions on food safety knowledge) was used to evaluate the overall knowledge of respondents. Food-handlers that obtained total score $\leq 16$ points were considered to have "insufficient" knowledge and those that had scores $\geq 17$ points ( $\geq 68 \%$ accuracy) were considered to have "good" knowledge of food safety.

Questions pertaining to attitudes (section 4) were aimed at determining the understanding of foodhandlers about food safety. Here, attitudes was used to mean "a complex mental state involving beliefs, feelings, values and dispositions to act in certain ways" [19]. This section had 20 statements/questions that required three possible responses: "agree", "disagree", and "don't know or remember". For evaluation, food-handlers that answered to 13 or less statements/questions correctly were measured to have "insufficient or poor" understanding, whereas those that responded to 14 or more statements/ questions correctly were measured to have "good" understanding.

In section five, which dealt with food hygiene practices, the good hygienic practices of respondents (institutional food-handlers) were assessed and evaluated based on self-reporting of personal hygiene and other safe food handling practices. The section had 11 statements/questions with two possible responses: "yes", and "no". Each correct practice reported scored one (1) point. For evaluation, a score $\geq 70 \%$ by an individual respondent was considered as having "good" food hygienic practice.

\section{Statistical analyses}

The statistical package for social science (SPSS) for Windows (version 11.0, 2001, Chicago, IL) was used for analyses of data. Difference in means were considered statistically significant at $p<0.05$. Mean scores of responses were converted into percentages for purposes of easy interpretation of results. One way analysis of variance (ANOVA) was used to compare the mean scores of knowledge, attitude, and practice among the different educational levels of respondents. The mean score of knowledge, attitude, and practice were compared by $t$ test. The responses were also reclassified into two categorical responses 'yes' and 'no' for correct and incorrect responses respectively.

In order to identify the variables that impacted on the observed results, four logistic regression analysis models were developed. The four models included knowledge of foodborne diseases, knowledge and attitudes regarding personal hygiene, knowledge and attitudes regarding temperature control, and knowledge and attitudes towards food hygienic practices. Predictive variables including age, length of employment and education level were incorporated into all models with general knowledge on food safety as the dependent variable.

\section{Results and discussion \\ Demographic characteristics}

Table 1 presents the summarized demographic profile of respondents in this study. Out of the 235 food-handlers who participated in this study, $76.6 \%(n=180)$ were female while $23.4 \%(n=55)$ were males. Most studies have reported higher proportion of females $[22,25,26]$ involvement in food handling. A greater number (39.1\%) of the participants were in the age bracket of $41-50$ years with average age of $41.5 \pm 9.5$ years. Similar studies showed that workers in older age brackets had better hygiene scores than their younger colleagues $[27,28]$. Approximately $14.5 \%$ of the participants in this study did not have any formal education. However, a previous study demonstrated that irrespective of educational level, employees performance in food safety knowledge was not satisfactory and thus a cause for public concern [29]. A greater number of participants $(76.2 \%)$ had $>5$ years of experience working in the foodservice industry with an average length of $11 \pm$ 7.8 years. Eighty three percent were full time workers in the institutions whiles the rest were part time workers. Only a few $(8.1 \%)$ of the respondents self-reported that they have ever received training in food safety. Although several studies have shown that training may contribute to upgrading the food safety knowledge of food-handlers, this does not always translate into a positive change in food handling behavior and attitudes [12,30].

\section{Employees' work satisfaction}

Work satisfaction was surveyed to ascertain institutional food-handler's satisfaction with the conditions, work load, work relations and other people reaction toward them (Table 2). In general, $24.7 \%$ of the 
Table 1 Demographic characteristics of institutional food-handlers in Ghana $(n=235)$

\begin{tabular}{|c|c|c|c|c|}
\hline Characteristics & Number & Percent & Mean \pm SD & Range \\
\hline \multicolumn{5}{|l|}{ Gender } \\
\hline Female & 180 & 76.6 & & \\
\hline Male & 55 & 23.4 & N/A & N/A \\
\hline \multicolumn{5}{|l|}{ Age (years) } \\
\hline $21-30$ & 18 & 7.7 & & \\
\hline $31-40$ & 78 & 33.2 & & \\
\hline $41-50$ & 92 & 39.1 & & \\
\hline $51-60$ & 47 & 20.0 & $41.5 \pm 9.5$ & $22-60$ \\
\hline \multicolumn{5}{|l|}{ Marital status } \\
\hline Single & 24 & 10.2 & & \\
\hline Married & 161 & 68.5 & & \\
\hline Divorced & 19 & 8.1 & & \\
\hline Widow/widower & 31 & 13.2 & & \\
\hline \multicolumn{5}{|l|}{ Education } \\
\hline No formal education & 34 & 14.5 & & \\
\hline Basic & 91 & 38.7 & & \\
\hline JHS/JSS & 57 & 24.3 & & \\
\hline SHS/SSS & 13 & 5.5 & & \\
\hline Post-secondary/Nocational & 22 & 9.4 & & \\
\hline Tertiary & 18 & 7.6 & & \\
\hline \multicolumn{5}{|l|}{ Length of employment (years) } \\
\hline$<5$ & 56 & 23.8 & & \\
\hline $5-10$ & 61 & 25.9 & & \\
\hline $11-20$ & 109 & 46.4 & & \\
\hline $21-30$ & 9 & 38.3 & $11 \pm 7.8$ & $0.5-30$ \\
\hline \multicolumn{5}{|l|}{ Employment status } \\
\hline Full-time & 197 & 83.8 & & \\
\hline Part-time & 38 & 16.2 & & \\
\hline \multicolumn{5}{|l|}{ Food safety training course } \\
\hline Yes & 19 & 8.1 & & \\
\hline No & 216 & 91.9 & & \\
\hline
\end{tabular}

institutional food-handlers affirmed that if they had to choose a profession again, they would choose the same profession, $48.5 \%$ said they would not choose the same profession, whiles $26.8 \%$ were indifferent about the issue of choosing a profession again.

In answering the question; would you quit this work if you are offered something better at a different place, about $95.3 \%$ affirmed they will leave while $4.7 \%$ were not certain. About $62.1 \%$ said the workplace make available all the necessary conditions for guaranteeing food safety. On the issue of sharing problems, $64.3 \%$ agreed that they do share their personal problems with their head of departments.

\section{Food safety knowledge of food-handlers}

In our study, the food-handlers were knowledgeable about hygiene practices, cleaning and sanitation procedures (Table 3). Majority of food-handlers in this study knew the importance of general sanitary practices such as regular hand washing at the work place $(98.7 \%$ correct answers), wearing of gloves (77.9\% correct answers), proper cleaning $(86.4 \%$ correct answers) and detergent use $(72.8 \%)$.

The awareness of such important hygienic procedures by majority of the institutional food-handlers in this study is very appropriate. This is because the hands of food-handlers can serve as vectors in the spread of foodborne diseases due to poor personal hygiene or crosscontamination [14, 31]. Proper hand washing by foodhandlers has been reported to significantly decrease the threat of diarrheal disease in child care facilities [32] and can therefore be encouraged as it could similarly help minimize the risk of diarrhea and other foodborne diseases in similar institutions. Despite a self-reported hand washing practiced by food-handlers, many employees' in a study by Stepanović et al. [33] had coagulase-positive staphylococci isolated from their hands, and this could be a source of food contamination. Therefore, it is prudent to combine proper hand washing with the wearing of gloves and other hygienic practices in order to

Table 2 Employees' work satisfaction

\begin{tabular}{|c|c|c|c|}
\hline \multirow[t]{2}{*}{ Statement/question } & \multicolumn{3}{|c|}{ Response \% (n) } \\
\hline & Yes & No & Don't know \\
\hline If you could choose a profession, would you choose this same profession? & $24.7(58)$ & $48.5(114)$ & $26.8(63)$ \\
\hline When you have personal trouble, do you share with your colleagues? & $60.0(141)$ & $40.0(94)$ & $0(0)$ \\
\hline When you have personal trouble, did you share with your head of department? & $64.3(151)$ & $35.7(84)$ & $0(0)$ \\
\hline Would you leave this work if you are offered something better at another place? & $95.3(224)$ & $0.0(0)$ & $4.7(11)$ \\
\hline Is the work load adequate? & $92.3(217)$ & $7.7(18)$ & $0(0)$ \\
\hline Is the kitchen staff respected by other workers of the institution? & $14.9(35)$ & $85.1(200)$ & $0(0)$ \\
\hline Does the workplace provide all the necessary conditions to guaranteeing food safety? & $62.1(146)$ & $37.9(89)$ & $0(0)$ \\
\hline Do the meals served present health risks to the people? & $0(0)$ & $100.0(235)$ & $0(0)$ \\
\hline
\end{tabular}


Table 3 Food safety knowledge of institutional food-handlers in Ghana

\begin{tabular}{|c|c|c|c|}
\hline \multirow[t]{2}{*}{ Statement } & \multicolumn{3}{|c|}{ Response \% (n) } \\
\hline & Correct & Incorrect & Don't know/remembe \\
\hline Washing hands before work reduces the risk of food contamination. & $98.7(232)$ & $0.0(0)$ & $1.3(3)$ \\
\hline Using gloves while handling food reduces the risk of food contamination. & $77.9(183)$ & $17.4(41)$ & $4.7(11)$ \\
\hline Proper cleaning and sanitization of utensils increase the risk of food contamination. & $4.7(11)$ & $86.4(203)$ & $8.9(21)$ \\
\hline Eating and drinking at the work place increase the risk of food contamination. & $25.1(59)$ & $60.9(143)$ & $14.0(33)$ \\
\hline Food prepared in advance reduces the risk of food contamination. & $21.3(50)$ & $68.1(160)$ & $10.6(25)$ \\
\hline Reheating cooked foods can contribute to food contamination. & $11.5(27)$ & $70.6(166)$ & $17.9(42)$ \\
\hline Washing utensils with detergent leaves them free of contamination. & $72.8(171)$ & $26.8(63)$ & $0.4(1)$ \\
\hline $\begin{array}{l}\text { Children, healthy adults, pregnant women and older individuals are at equal risk } \\
\text { for food poisoning. }\end{array}$ & $60.9(143)$ & $37.9(89)$ & $1.2(3)$ \\
\hline Typhoid fever can be transmitted by food. & $81.7(192)$ & $13.6(32)$ & $4.7(11)$ \\
\hline AIDS can be transmitted by food. & $8.5(20)$ & $86.8(204)$ & $4.7(11)$ \\
\hline Bloody diarrhea can be transmitted by food. & $87.7(206)$ & $8.1(19)$ & $4.2(10)$ \\
\hline Salmonella is among the food-borne pathogens. & $18.3(43)$ & $5.5(13)$ & $76.2(179)$ \\
\hline Hepatitis A virus is among the food-borne pathogens. & $11.5(27)$ & $17.9(42)$ & $70.6(166)$ \\
\hline Swollen cans may contain the microorganism, Clostridium botulinum, which causes botulism. & $13.6(32)$ & $10.2(24)$ & $76.2(179)$ \\
\hline Microbes are on the skin, in the nose and mouth of healthy food handlers. & $71.5(168)$ & $25.1(59)$ & $3.4(8)$ \\
\hline Clean is the same as sanitized. & $60.0(141)$ & $33.6(79)$ & $6.4(15)$ \\
\hline $\begin{array}{l}\text { Cross contamination is when microorganisms from a contaminated food are transferred } \\
\text { by the food handler's hands or kitchen utensils to another food. }\end{array}$ & $4.7(11)$ & $8.9(21)$ & $86.4(203)$ \\
\hline The correct temperature for storing perishable foods is $5^{\circ} \mathrm{C}$. & $33.6(79)$ & $6.4(15)$ & $60.0(141)$ \\
\hline Hot, ready-to-eat food should be kept at a temperature of $65^{\circ} \mathrm{C}$. & $60.0(141)$ & $6.4(15)$ & $33.6(79)$ \\
\hline Freezing kills all the bacteria that may cause food-borne illness. & $59.1(139)$ & $39.2(92)$ & $1.7(4)$ \\
\hline Contaminated foods always have some change in color, odor or taste. & $60.4(142)$ & $39.2(92)$ & $0.4(1)$ \\
\hline Raw vegetables are at higher risk of contamination than undercooked beef & $40.9(96)$ & $28.9(68)$ & $30.2(71)$ \\
\hline During infectious disease of the skin, it is necessary to take leave from work. & $93.6(220)$ & $0.0(0)$ & $6.4(15)$ \\
\hline The health status of workers should be evaluated before employment. & $99.6(234)$ & $0.4(1)$ & $0.0(0)$ \\
\hline The ideal place to store raw meat in the refrigerator is on the bottom shelf. & $40.9(96)$ & $28.9(68)$ & $30.2(71)$ \\
\hline
\end{tabular}

minimize the risk of contamination during food handling [34].

Regarding foodborne disease transmission, $76.2 \%$ of the food-handlers (respondents) did not know or remember that Salmonella is a food-borne pathogens and $70.6 \%$ did not know/remember that hepatitis A is a foodborne pathogen. On the other, 81.7 and $87.7 \%$ of respondents agreed that typhoid fever and bloody diarrhea respectively can be transmitted by food. The majority (86.8\%) of respondents disagreed that HIV/AIDS is transmitted by food, which is an indication that public education on HIV/AIDS by the Ghana AIDS commission could be yielding results. These results support recently published work where majority of the respondents did not know if Salmonella, hepatitis A and B viruses, and Staphylococcus caused foodborne diseases [13, 22]. Over ninety percent $(90 \%)$ of respondents agreed that taking leave from work in periods of infectious skin disease was necessary (Table 3). Additionally, 71.5\% knew that microorganisms can be found on the skin and in the mouth and nose of healthy looking individuals. They also recognize that the health status of food-handlers should be assessed prior to employment.

On the other hand, food-handlers were less familiar with time and temperature abuse and its effect on food safety (Table 3). Anon [35] reported that improper handling of food, including the abuse of timetemperature, account for most food-borne disease outbreak. In this study, respondents had insufficient knowledge on time-temperature controls. This result is supported by others $[14,29]$ whose report show that knowledge of critical temperatures were insufficient amongst food-handlers. Similar findings on the lack of adequate knowledge on temperature controls by food-handlers have also been reported from different countries [36-38]. 
Food safety attitudes of food-handlers

A reduction in the incidence of food-borne illnesses is strongly influenced by the attitudes of food-handlers towards the implementation of food safety plans. Thus, there is a strong linkage between positive behavior, attitudes and education of food-handlers in maintaining safe food handling practices [12].

Table 4 shows the attitudes of the food-handlers toward the prevention and control of food-borne diseases. About $60 \%$ of respondents indicated that using caps, masks, protective gloves and proper clothing can minimize the risk of food contamination, which is a positive attitude reported by majority of the respondents. Similarly, majority of respondents (93.6\%) agreed that knives and cutting boards should be properly sanitized to prevent cross contamination of foods. Respondents also agreed that individuals with abrasions or cuts on their fingers or hands should not touch unwrapped foods $(87.2 \%)$. The majority (88.1\%) of food-handlers were aware that food should not be handled with long and painted fingernails. They were also mindful of the fact that dish towels could cross-contaminate foods (71.5\%) and that well-cooked foods are free of contamination $(86.4 \%)$. Thus, the general attitudes of the foodhandlers toward food safety was satisfactory, except on issues relating to refrozen of defrosted food. About $81.7 \%$ of food-handlers had unsatisfactory attitude towards defrosted and refrozen foods. Refreezing a completely thawed food can present a serious health risk, as this process leads faster growth of contaminating bacteria. Freezing food only slows bacterial growth and does not necessarily kill the pathogens [39]. Respondents (86.4\%) did not find it necessary to check the temperatures of refrigerators and freezers periodically (86.4\%).

\section{Food safety practices by food-handlers}

Table 5 shows the food safety practices by institutional food-handlers. In assessing the food safety practices of the institutional food-handlers, $88.1 \%$ reported that they do not use gloves during the distribution of unpackaged foods. Majority (61.7\%) of the food-handlers do not use aprons or wear mask when necessary. Additionally, they eat and drink during working hours. On sanitizer use, $61.7 \%$ reported that they do not use sanitizer in washing utensils such as plates, mugs and spoons. All respondents reported that they do not use sanitizer when washing fruits or vegetables. About $83.8 \%$ of the institutional food-handlers do prepare meals in advance. Only $17 \%$ of respondents reported that they look out for the shelf-life of foods when taking delivery of them.

Some previous studies suggest that the lack of knowledge in food safety can lead to poor hygienic practices by food-handlers [27, 40]. However, Clayton et al. [41] reported that about $63 \%$ of food-handlers demonstrating
Table 4 Food safety attitudes of institutional food-handlers

\begin{tabular}{|c|c|c|c|}
\hline \multirow[t]{2}{*}{ Statement } & \multicolumn{3}{|c|}{ Response \% (n) } \\
\hline & Agree & Disagree & $\begin{array}{l}\text { Don't know/ } \\
\text { remember }\end{array}$ \\
\hline $\begin{array}{l}\text { Well-cooked foods are free of } \\
\text { contamination }\end{array}$ & 86.4 (203) & $8.9(21)$ & $4.7(11)$ \\
\hline $\begin{array}{l}\text { Proper hand hygiene can prevent } \\
\text { food-borne diseases. }\end{array}$ & $93.6(220)$ & $0.0(0)$ & $6.4(15)$ \\
\hline $\begin{array}{l}\text { When cleaning products are } \\
\text { closed, they can be stored with } \\
\text { cans and jars of food that are } \\
\text { also closed. }\end{array}$ & $28.9(68)$ & $30.2(71)$ & $40.9(96)$ \\
\hline $\begin{array}{l}\text { Raw and cooked foods should } \\
\text { be stored separately to reduce } \\
\text { the risk of food contamination. }\end{array}$ & $40.9(96)$ & $28.9(68)$ & $30.2(71)$ \\
\hline $\begin{array}{l}\text { It is necessary to check the } \\
\text { temperature of refrigerators/ } \\
\text { freezers periodically to reduce } \\
\text { the risk of food contamination. }\end{array}$ & $33.6(79)$ & $8.9(21)$ & 86.4 (203) \\
\hline $\begin{array}{l}\text { Defrosted foods should not } \\
\text { be refrozen. }\end{array}$ & $13.6(32)$ & 81.7 (192) & $4.7(11)$ \\
\hline $\begin{array}{l}\text { The health status of workers } \\
\text { should be evaluated before } \\
\text { employment. }\end{array}$ & $60.0(141)$ & $6.4(15)$ & $33.6(79)$ \\
\hline $\begin{array}{l}\text { The best way to thaw a chicken } \\
\text { is in a bowl of cold water. }\end{array}$ & 87.7 (206) & $8.1(19)$ & $4.2(10)$ \\
\hline $\begin{array}{l}\text { Wearing masks is an important } \\
\text { practice to reduce the risk of food } \\
\text { contamination. }\end{array}$ & $60.0(141)$ & $6.4(15)$ & $33.6(79)$ \\
\hline $\begin{array}{l}\text { Wearing gloves is an important } \\
\text { practice to reduce the risk of food } \\
\text { contamination. }\end{array}$ & $60.0(141)$ & $6.4(15)$ & $33.6(79)$ \\
\hline $\begin{array}{l}\text { Wearing caps and adequate } \\
\text { clothing is an important practice } \\
\text { to reduce the risk of food } \\
\text { contamination. }\end{array}$ & $60.0(141)$ & $6.4(15)$ & $33.6(79)$ \\
\hline $\begin{array}{l}\text { Safe food handling is an important } \\
\text { part of my job responsibilities }\end{array}$ & $40.9(96)$ & $28.9(68)$ & $30.2(71)$ \\
\hline $\begin{array}{l}\text { Learning more about food safety } \\
\text { through training courses is } \\
\text { important to me }\end{array}$ & $30.2(71)$ & $28.9(68)$ & $40.9(96)$ \\
\hline $\begin{array}{l}\text { Beards could contaminate food } \\
\text { with foodborne pathogens }\end{array}$ & $13.6(32)$ & $10.2(24)$ & 76.2(179) \\
\hline $\begin{array}{l}\text { Long and painted fingernails } \\
\text { could contaminate food with } \\
\text { foodborne pathogens. }\end{array}$ & $88.1(207)$ & $11.9(28)$ & $0(0)$ \\
\hline $\begin{array}{l}\text { Food handlers can be a source of } \\
\text { foodborne outbreaks }\end{array}$ & $64.3(151)$ & $35.7(84)$ & $0(0)$ \\
\hline $\begin{array}{l}\text { Eggs must be washed immediately } \\
\text { after delivery. }\end{array}$ & $24.7(58)$ & 48.5 (114) & $26.8(63)$ \\
\hline $\begin{array}{l}\text { Dish towels can be a source of } \\
\text { food contamination. }\end{array}$ & 71.5 (168) & $25.1(59)$ & $3.4(8)$ \\
\hline $\begin{array}{l}\text { Knives and cutting boards should } \\
\text { be properly sanitized to prevent } \\
\text { cross contamination. }\end{array}$ & $93.6(220)$ & $0(0)$ & $6.4(15)$ \\
\hline $\begin{array}{l}\text { Food handlers who have abrasions } \\
\text { or cuts on their hands should not } \\
\text { touch foods without gloves. }\end{array}$ & $87.2(207)$ & $0(0)$ & $12.8(30)$ \\
\hline
\end{tabular}


Table 5 Food safety practices among institutional foodhandlers

\begin{tabular}{lll}
\hline Question & \multicolumn{2}{l}{ Response \% (n) } \\
\cline { 2 - 3 } & Yes & No \\
\hline $\begin{array}{l}\text { Do you use gloves during the distribution } \\
\text { of unpackaged foods? }\end{array}$ & $11.9(28)$ & $88.1(207)$ \\
If no, go to question 3. & & \\
$\begin{array}{l}\text { Do you wash your hands properly before } \\
\text { or after using gloves? }\end{array}$ & $64.2(18)$ & $35.7(10)$ \\
$\begin{array}{l}\text { Do you wear an apron while working? } \\
\begin{array}{l}\text { Do you wear a mask when you distribute } \\
\text { unwrapped foods? }\end{array}\end{array}$ & $38.3(90)$ & $61.7(145)$ \\
$\begin{array}{l}\text { Do you eat or drink at your work place? } \\
\text { Do you wear nail polish when handling }\end{array}$ & $93.6(220)$ & $61.7(145)$ \\
food? & $16.2(38)$ & $83.8(15)$ \\
$\begin{array}{l}\text { Do you prepare a meal in advance (i.e., } \\
\text { from one shift to another)? }\end{array}$ & $83.8(197)$ & $16.2(38)$ \\
$\begin{array}{l}\text { Do you properly clean the food storage } \\
\text { area before storing new products? }\end{array}$ & $87.2(207)$ & $12.8(30)$ \\
$\begin{array}{l}\text { Do you use the sanitizer when washing } \\
\text { service utensils (plates, mugs and spoons)? }\end{array}$ & $61.7(145)$ & $38.3(90)$ \\
$\begin{array}{l}\text { Do you use the sanitizer when washing } \\
\text { fruits? }\end{array}$ & $0.0(0)$ & 100 (235) \\
$\begin{array}{l}\text { Do you check the shelf life of foods at } \\
\text { the time of delivery? }\end{array}$ & $17(40)$ & $83(195)$ \\
\hline & & \\
\hline
\end{tabular}

knowledge in food safety did not demonstrate a corresponding positive behavior towards food safety/hygienic practices. This shows that food-handlers might not necessarily be practicing strict food safety procedures during food handling, even when they provide answers to show that they are knowledgeable in a survey. Therefore, other factors such as employee motivation and continuous education and training on the job should be provided to inspire food-handlers, which will affect attitudes and subsequently food-safety practices [42].

\section{Logistic regression analyses}

Logistic regression analysis testing four models to identify the variables that impacted on the observed results are shown in Table 6. All models tested except model 2 showed statistically significant differences $(p<0.05)$. The significant differences were only observed for models in which the explanatory variable was the level of education. Thus with the exception of model 2, respondents having advanced specific knowledge demonstrated significantly better understanding of food safety issues. For example, in model 1, the results indicate that food-handlers that demonstrate good knowledge of Hepatitis A virus as a foodborne pathogen had an adjusted OR of $14.3\left(\mathrm{Cl}_{95}, P=\right.$ 0.002). Thus, these food-handlers have 14.3 more times possibilities of having good level of food safety knowledge when compared with food-handlers lacking sufficient level of knowledge for the same variable.
Table 6 Logistic regression analyses

\begin{tabular}{|c|c|c|}
\hline Variables & OR adjusted & $P$-value \\
\hline \multicolumn{3}{|l|}{ Model 1} \\
\hline $\begin{array}{l}\text { Knowledge about risk group for } \\
\text { food-borne disease }\end{array}$ & 14.2 & 0.001 \\
\hline $\begin{array}{l}\text { Knowledge about HIV as a food-borne } \\
\text { disease }\end{array}$ & 8.4 & 0.004 \\
\hline $\begin{array}{l}\text { Knowledge about Hepatitis virus as a } \\
\text { food-borne pathogen }\end{array}$ & 14.3 & 0.002 \\
\hline $\begin{array}{l}\text { Knowledge about Staphylococcus as a } \\
\text { food-borne pathogen }\end{array}$ & 3.9 & 0.017 \\
\hline $\begin{array}{l}\text { Knowledge about Clostridium as a } \\
\text { food-borne pathogen }\end{array}$ & 7.6 & 0.002 \\
\hline $\begin{array}{l}\text { Knowledge about microorganisms versus } \\
\text { health of food handlers }\end{array}$ & 13.2 & 0.003 \\
\hline Level of education & 5.1 & 0.000 \\
\hline \multicolumn{3}{|l|}{ Model 2} \\
\hline Knowledge of gloves use & 0.8 & 0.104 \\
\hline Knowledge of masks use & 1.3 & 0.052 \\
\hline $\begin{array}{l}\text { Knowledge about eating or drinking } \\
\text { during working hours }\end{array}$ & 1.4 & 0.080 \\
\hline $\begin{array}{l}\text { Practice about eating or drinking } \\
\text { during working hours }\end{array}$ & 2.5 & 0.063 \\
\hline Level of education & 4.2 & 0.030 \\
\hline \multicolumn{3}{|l|}{ Model 3} \\
\hline $\begin{array}{l}\text { Knowledge about freezing versus } \\
\text { microorganisms }\end{array}$ & 3.8 & 0.003 \\
\hline Knowledge about refrigeration temperature & 3.5 & 0.001 \\
\hline Level of education & 3.9 & 0.004 \\
\hline \multicolumn{3}{|l|}{ Model 4} \\
\hline $\begin{array}{l}\text { Knowledge about food contamination versus } \\
\text { attributes of food that may indicate } \\
\text { contamination }\end{array}$ & 6.4 & 0.010 \\
\hline Knowledge of shelf-life & 3.5 & 0.003 \\
\hline Level of education & 4.5 & 0.001 \\
\hline
\end{tabular}

\section{Conclusions}

In general, institutional food-handlers in Ghana had satisfactory knowledge in the areas of food safety, general and personal hygiene, cleaning and sanitation procedures. However, this did not translate into strict food hygiene practices. Therefore continuous food safety education and motivation for foodhandlers of various demographic backgrounds with special attention paid to those with lower levels of education would complement other interventions that pursue the enhancement of food safety systems in Ghana.

\section{Abbreviations}

AIDS: Acquired immune deficiency syndrome; HACCP: Hazard analysis critical control point; JHS/JSS: Junior high school/junior secondary school; KAP: Knowledge attitude and practice; SHS/SSS: Senior high school/senior secondary school; WHO: World health organization 


\section{Acknowledgements}

The authors would like to thank the staff and the participants of the various institutions visited for their contributions.

\section{Funding}

None.

\section{Availability of data and materials}

The authors declare that the data supporting the findings of this study are fully described within the manuscript.

\section{Authors' contributions}

FA and JOK designed the study, analyzed and interpreted the data, discussed the results, wrote, edited and drafted the paper with equal contributions at all levels. EHH participated in the design of questionnaire, collected and complied the data. All authors have read and approved the final version of the manuscript.

\section{Author details}

FA and JOK are both lecturers at the Department of Applied Biology, Faculty of Applied Sciences, University for Development Studies, P. O. Box 24, Navrongo-campus, Ghana. EHH is a graduate assistant at the University for Development Studies, Ghana.

\section{Competing interests}

All the authors declare that they do not have any competing interests.

\section{Consent to publish}

Not applicable. The published data does not contain details that could be traced to any individual respondent.

\section{Ethics approval and consent to participate}

All respondents provided written informed consent before participating in the study. The study was considered to belong to exempt category review for ethical approval due to minimal risk to respondents. Waiver from approval was discussed with, and granted by the Navrongo Health Research Center Institutional Review Board (NHRCIRB), Ghana.

Received: 18 June 2016 Accepted: 22 December 2016

Published online: 06 January 2017

\section{References}

1. Adams M, Motarjemi Y. Basic food safety for health workers. Geneva: World Health Organization; 1999. p. 113-4.

2. Annor GA, Baiden EA. Evaluation of food hygiene knowledge attitudes and practices of food handlers in food businesses in Accra, Ghana. Food Nutr Sci. 2011;2(8):830.

3. Omaye ST. Food and nutritional toxicology. Boca Raton: CRC press; 2004. p. 163-73.

4. WHO. Food Safety and Foodborne IIIness. Fact sheets No. 237. Geneva: World Health Organization; 2007.

5. Barrie D. The provision of food and catering services in hospital. J Hosp Infect. 1996:33(1):13-33.

6. Jay LS, Comar D, Govenlock LD. A video study of Australian domestic foodhandling practices. J Food Prot. 1999:62(11):1285-96.

7. Fielding JE, Aguirre A, Palaiologos E. Effectiveness of altered incentives in a food safety inspection program. Prev Med. 2001;32(3):239-44.

8. Gent R, Telford D, Syed Q: An outbreak of campylobacter food poisoning at a university campus. Communicable disease and public health/PHLS 1999, 2(1):39-42

9. WHO. Strategies for implementing HACCP in small and/or less developed businesses, The Hague, 16-19 June, 1999. Geneva: World Health Organisation, WHO/SDE/FOS/99.7; 1999.

10. Ehiri JE, Morris GP. Hygiene training and education of food handlers: does it work? Ecol Food Nutr. 1996;35(4):243-51.

11. Greig JD, Todd EC, Bartleson CA, Michaels BS. Outbreaks where food workers have been implicated in the spread of foodborne disease. Part 1. Description of the problem, methods, and agents involved. J Food Prot. 2007;70(7):1752-61.
12. Howes M, McEwen S, Griffiths M, Harris L. Food handler certification by home study: Measuring changes in knowledge and behavior. Dairy, Food Environ Sanit. 1996;16(11):737-44.

13. Ansari-Lari M, Soodbakhsh S, Lakzadeh L. Knowledge, attitudes and practices of workers on food hygienic practices in meat processing plants in Fars, Iran. Food Control. 2010;21(3):260-3.

14. Baş M, Ersun AŞ, Kıvanç G. The evaluation of food hygiene knowledge, attitudes, and practices of food handlers' in food businesses in Turkey. Food Control. 2006:17(4):317-22

15. Capunzo M, Cavallo P, Boccia G, Brunetti L, Buonomo R, Mazza G. Food hygiene on merchant ships: the importance of food handlers' training. Food Control. 2005;16(2):183-8.

16. Jevšnik $M$, Hlebec $V$, Raspor P. Food safety knowledge and practices among food handlers in Slovenia. Food Control. 2008;19(12):1107-18

17. Martins RB, Hogg T, Otero JG. Food handlers' knowledge on food hygiene: The case of a catering company in Portugal. Food Control. 2012;23(1):184-90.

18. Seaman P, Eves A. Perceptions of hygiene training amongst food handlers, managers and training providers-A qualitative study. Food Control. 2010; 21(7):1037-41.

19. Sharif L, Al-Malki T. Knowledge, attitude and practice of Taif University students on food poisoning. Food Control. 2010;21(1):55-60.

20. Boateng AE. Assessment of food hygiene practices by street food vendors and microbial quality of selected foods sold. A study at Dunkwa-On-Offin, Upper Denkyira East municipality of the Central Region. Kumasi, Ghana: Kwame Nkrumah University of Science and Technology; 2014.

21. Kunadu AP-H, Ofosu DB, Aboagye E, Tano-Debrah K. Food safety knowledge, attitudes and self-reported practices of food handlers in institutional foodservice in Accra, Ghana. Food Control. 2016:69:324-30.

22. Soares LS, Almeida RC, Cerqueira ES, Carvalho JS, Nunes IL. Knowledge, attitudes and practices in food safety and the presence of coagulasepositive staphylococci on hands of food handlers in the schools of Camaçari, Brazil. Food Control. 2012;27(1):206-13.

23. Angelillo IF, Viggiani NM, Greco RM, Rito D. HACCP and food hygiene in hospitals knowledge, attitudes, and practices of food-services staff in Calabria, Italy. Infect Control Hosp Epidemiol. 2001;22(06):363-9.

24. Bolton D, Meally A, Blair I, McDowell D, Cowan C. Food safety knowledge of head chefs and catering managers in Ireland. Food Control. 2008;19(3):291-300.

25. Baluka SA, Miller R, Kaneene JB. Hygiene practices and food contamination in managed food service facilities in Uganda. Afr J Food Sci. 2015;9(1):31-42

26. Son R, Mohhiddin O, Toh P, Chai L. Food court hygiene assessment and food safety knowledge, attitudes and practices of food handlers in Putrajaya. Int Food Res J. 2015;22(5):1843-54.

27. Çakıroğlu FP, Uçar A. Employees' perception of hygiene in the catering industry in Ankara (Turkey). Food Control. 2008;19(1):9-15.

28. Olumakaiye MF, Bakare KO. Training of food providers for improved environmental conditions of food service outlets in urban area Nigeria. Food Nutr Sci. 2013:4(07):99.

29. Webb M, Morancie A. Food safety knowledge of foodservice workers at a university campus by education level, experience, and food safety training. Food Control. 2015;50:259-64.

30. Powell S, Attwell R, Massey S. The impact of training on knowledge and standards of food hygiene Eth a pilot study. Int J Environ Health Res. 1997; 7(4):329-34.

31. Fuerst R. Frobisher and FuerstÕs microbiology in health and disease: Foods as vectors of microbial disease. Sanitation in food handling (15th ed.). Philadelphia: W.B. Saunders Company; 1983. p. 418-33.

32. Xavier CAC, Oporto CO, Silva MP, Silveira IA, Abrantes MR. Prevalência de Staphylococcus aureus em manipuladores de alimentos das creches municipais da cidade do Natal/RN. Revista Brasileira de Análises Clínicas. 2007;39(3):165-8.

33. Stepanović S, Dakić I, Morrison D, Hauschild T, Ježek P, Petráš P, Martel A, Vuković D, Shittu A, Devriese LA. Identification and characterization of clinical isolates of members of the Staphylococcus sciuri group. J Clin Microbiol. 2005;43(2):956-8.

34. Montville R, Chen Y, Schaffner DW. Glove barriers to bacterial crosscontamination between hands to food. J Food Prot. 2001;64(6):845-9.

35. Anon.: Acute gastroenteritis in Ireland, north and south: a telephone survey. In: Health Protection Surveillance Centre. 25e27 Middle Gardiner Street, Dublin I, Ireland; 2003

36. Buccheri C, Casuccio A, Giammanco S, Giammanco M, La Guardia M, Mammina C. Food safety in hospital: knowledge, attitudes and practices of nursing staff of two hospitals in Sicily, Italy. BMC Health Serv Res. 2007;7(1):1. 
37. Marais M, Conradie N, Labadarios D. Small and micro enterprises-aspects of knowledge, attitudes and practices of managers'and food handlersl'knowledge of food safety in the proximity of Tygerberg Academic Hospital, Western Cape. South Afr J Clin Nutr. 2008;20(2):50-61.

38. Walker E, Pritchard C, Forsythe S. Food handlers' hygiene knowledge in small food businesses. Food Control. 2003;14(5):339-43.

39. Julie GR: Food Safety Basics. A Reference Guide for Foodservices Operators. In., vol. 1; 2012: 5-6

40. Lambiri M, Mavridou A, Papadakis J. The application of hazard analysis critical control point (HACCP) in a flight catering establishment improved the bacteriological quality of meals. J R Soc Promot Heal. 1995;115(1):26-30

41. Clayton DA, Griffith CJ, Price P, Peters AC. Food handlers' beliefs and selfreported practices. Int J Environ Health Res. 2002;12(1):25-39.

42. Huda N: Tahap pengetahuan, sikap dan amalan kebersihan dan keselamatan makanan di kalangan pengendali makanan di hospital. MSC Thesis, Universiti Kebangsaan Malaysia, Bangi; 2008

Submit your next manuscript to BioMed Central and we will help you at every step:

- We accept pre-submission inquiries

- Our selector tool helps you to find the most relevant journal

- We provide round the clock customer support

- Convenient online submission

- Thorough peer review

- Inclusion in PubMed and all major indexing services

- Maximum visibility for your research

Submit your manuscript at www.biomedcentral.com/submit
Biomed Central 